\title{
Characteristics of Scratching Behavior Induced by Some Chemical Mediators in Hairless Mice
}

\author{
Miho Takubo ${ }^{1}$, Yuhki Ueda ${ }^{1}$, Rie Yatsuzuka ${ }^{1}$, Shuishi Jiang ${ }^{1}$, Yoko Fujii ${ }^{1}$, and Chiaki Kamei ${ }^{1}{ }^{*}$ \\ ${ }^{1}$ Department of Medicinal Pharmacology, Okayama University Graduate School of Medicine, Dentistry \\ and Pharmaceutical Sciences, Okayama 700-8530, Japan
}

Received January 20, 2006; Accepted February 14, 2006

\begin{abstract}
To find the characteristics of scratching behavior in hairless mice (HR-1), compound 48/80 and some putative chemical mediators of allergic reaction were injected intradermally into the backs of mice, and the number of scratching behaviors was measured. As reference mice, NC/Nga, ICR, and ddY mice were used. Scratching behavior in HR-1 and ICR mice was increased dose-dependently by compound 48/80. The same result was also observed with $\mathrm{NC} / \mathrm{Nga}$ and ddY mice. However, the response in NC/Nga and ddY mice was far less than those of HR-1 and ICR mice. Similar to NC/Nga and ddY mice, HR-1 mice showed less sensitivity to histamine than ICR mice. On the other hand, the HR-1 mice showed a high response to serotonin compared with those of the $\mathrm{NC} / \mathrm{Nga}$ and ddY mice. The scratching behavior in HR-1 mice induced by substance $\mathrm{P}$ was increased, but the effect was less potent than those in $\mathrm{NC} / \mathrm{Nga}$, ICR, and ddY mice. These results suggest that the scratching behavior induced by compound $48 / 80$ in HR-1 mice is mainly attributable to serotonin.
\end{abstract}

Keywords: scratching behavior, compound 48/80, serotonin, histamine, HR-1 mice

\section{Introduction}

Since the demonstration by Matsuda et al. (1), $\mathrm{NC} / \mathrm{Nga}$ mice $(2,3)$ bred under conventional or specific pathogen-free (SPF) conditions have been widely used as an atopic dermatitis model. This animal model is reported to be closely similar to human atopic dermatitis (4), but the fur of the mice must be shaved or clipped before the start of the experiment. It is well recognized that these procedures induce abrasion or irritation of the skin. In addition to the above reasons, $\mathrm{NC} / \mathrm{Nga}$ mice are not suitable for time-course studies of drug effect due to hair re-growth (5). On the other hand, hairless mice have been used frequently for skin cancer induced by ultraviolet rays or skin basic research $(5,6)$. It can be assumed that the skin of hairless mice resembles human glabrous skin, because of the lack of hair. In addition, similar to human beings, the thickness of the skin of hairless mice is about $0.40 \mathrm{~mm}$ at $8-10$ weeks of age (5). Therefore, it seems likely that it is easy

*Corresponding author. kamei@pheasant.pharm.okayama-u.ac.jp Published online in J-STAGE: March 25, 2006

DOI: 10.1254/jphs.FPJ06002X to produce artifactual lesions or to stimulate the skin of these mice. However, little is known about the scratching behavior induced by various chemical mediators using hairless mice. Therefore, we studied the scratching behavior induced by compound 48/80 and some putative chemical mediators of allergic reaction in hairless mice to develop a new atopic dermatitis model in animals in comparison with those of $\mathrm{NC} / \mathrm{Nga}$, ICR, and ddY mice.

\section{Materials and Methods}

\section{Animals}

Female HR-1 strain hairless mice (6-week-old; Hoshino Laboratory Animals, Saitama), NC/Nga mice (6-week-old; Japan SLC, Hamamatsu), ICR mice (6week-old, Japan SLC), and ddY mice (6-week-old, Japan SLC) were used in the study. The animals were housed in an air-conditioned room at $24 \pm 2{ }^{\circ} \mathrm{C}$ with a relative humidity of $55 \pm 15 \%$ and a 12 -h light and darkness cycle. They were fed a commercial MF diet (Oriental Yeast, Tokyo) and drinking water was given ad libitum. All procedures involving animals were conducted in accordance with the Guidelines for Animal 
Experiments at Okayama University Advanced Science Research Center.

\section{Drugs}

Compound 48/80 (Sigma, St. Louis, MO, USA), histamine dihydrochloride (Sigma), serotonin (Sigma), and substance P (Sigma) were used. These drugs were dissolved in saline and administered intradermally. Methysergide maleate (Sigma) was dissolved in distilled water and orally administered $1 \mathrm{~h}$ before intradermal injection of compound $48 / 80$.

\section{Scratching behavior}

Scratching behavior was automatically detected and objectively evaluated using MicroAct (Neuroscience, Tokyo), as reported by Inagaki et al (7). The animals were placed into an observation chamber for $10 \mathrm{~min}$ for acclimatization before the measurement of scratching behavior. The scratching behavior was defined as movement of the hind limb implanted magnets. The number of scratching behaviors was counted for $60 \mathrm{~min}$ after intradermal injection of drugs.

\section{Statistical analyses}

All values are expressed as the mean \pm S.E.M. Statistical analysis of the results were performed by one-way analysis of variance (ANOVA) followed by Dunnett's test. A probability value of less than 0.05 was considered statistically significant.

\section{Results}

\section{Compound 48/80-induced scratching behavior}

Compound 48/80 induced a dose-dependent increase in the number of scratching behaviors in HR-1, $\mathrm{NC} / \mathrm{Nga}$, ICR, and ddY mice. In HR-1 mice, a significant increase was observed at 3 and $10 \mu \mathrm{g} / \mathrm{site}$. In $\mathrm{NC} / \mathrm{Nga}$, a significant increase was observed from $1 \mu \mathrm{g} / \mathrm{site}$, although the extent was less than that in HR-1 mice. In ICR and ddY mice, a significant effect was observed at $10 \mu \mathrm{g} / \mathrm{site}$. The number of scratching behaviors in HR-1 mice was significantly more frequent than that in $\mathrm{NC} / \mathrm{Nga}(10 \mu \mathrm{g} / \mathrm{site})$ and ddY mice (3 and $10 \mu \mathrm{g} /$ site) (Fig. 1).

\section{Histamine-induced scratching behavior}

The results are shown in Table 1. In HR-1, NC/Nga, and ddY mice, histamine caused no significant increase in scratching behavior, even at a dose of $100 \mathrm{nmol} / \mathrm{site}$. On the other hand, in ICR mice, it showed a significant increase in scratching behavior at a dose of 100 $\mathrm{nmol} / \mathrm{site}$. There was a significant difference between HR-1 mice and ICR mice when injected with a dose of

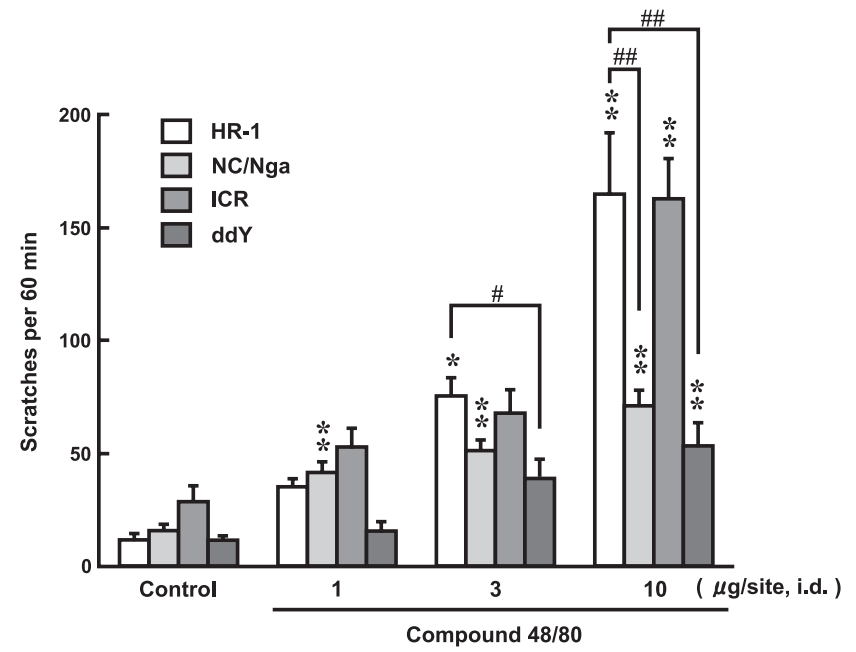

Fig. 1. Scratching behavior induced by compound 48/80 in HR-1, $\mathrm{NC} / \mathrm{Nga}, \mathrm{ICR}$, and ddY mice. Mice received an intradermal injection of 1,3 , and $10 \mu \mathrm{g} / \mathrm{site}$; and the scratching behavior was counted for $60 \mathrm{~min}$ after injection. Each value represents the mean \pm S.E.M. $(\mathrm{n}=8-10) .{ }^{*}, * *$ : Significantly different from the control group at $P<0.05$ and $P<0.01$, respectively. \#, \#\#: Significantly different from HR-1 mice at $P<0.05$ and $P<0.01$, respectively.

Table 1. Scratching behavior induced by histamine in HR-1, $\mathrm{NC} / \mathrm{Nga}$, ICR, and ddY mice

\begin{tabular}{lcc}
\hline Strains & Dose (nmol/site, i.d.) & Scratches per 60 min \\
\hline HR-1 & - & $11.4 \pm 2.7$ \\
& 10 & $12.8 \pm 1.7$ \\
& 100 & $28.8 \pm 2.9$ \\
NC/Nga & - & $15.3 \pm 3.2$ \\
& 10 & $20.7 \pm 2.2$ \\
ICR & 100 & $23.1 \pm 3.7$ \\
& - & $28.2 \pm 7.1$ \\
& 10 & $32.7 \pm 10.2$ \\
ddY & 100 & $72.8 \pm 16.1 *$,\# \\
& - & $11.4 \pm 1.9$ \\
& 10 & $13.4 \pm 2.8$ \\
& 100 & $14.4 \pm 2.7$ \\
\hline
\end{tabular}

${ }^{*} P<0.05$, compared with the control; ${ }^{\#} P<0.01$, compared with HR-1.

$100 \mathrm{nmol} / \mathrm{site}$ histamine.

\section{Serotonin-induced scratching behavior}

In both HR-1 and ICR mice, serotonin caused a dosedependent increase in the scratching behavior and a significant effect was observed at a dose of 100 $\mathrm{nmol} /$ site. In NC/Nga and ddY mice, serotonin also significantly increased scratching behavior at a dose of $100 \mathrm{nmol} / \mathrm{site}$; however, the extent was far less than that of HR-1 mice. The number of scratching behavior in 
Table 2. Scratching behavior induced by serotonin in HR-1, $\mathrm{NC} / \mathrm{Nga}$, ICR, and ddY mice

\begin{tabular}{lcc}
\hline Strains & Dose (nmol/site, i.d.) & Scratches per $60 \mathrm{~min}$ \\
\hline HR-1 & - & $11.4 \pm 2.7$ \\
& 10 & $48.6 \pm 13.6$ \\
& 100 & $140.9 \pm 17.7^{* *}$ \\
NC/Nga & - & $15.3 \pm 3.2$ \\
& 10 & $30.8 \pm 5.4$ \\
ICR & 100 & $46.6 \pm 7.0^{* *, \# \#}$ \\
& - & $28.2 \pm 7.1$ \\
& 10 & $68.7 \pm 12.7$ \\
ddY & 100 & $92.8 \pm 19.3^{* *}$ \\
& - & $11.4 \pm 1.9$ \\
& 10 & $11.9 \pm 2.4^{\#}$ \\
& 100 & $27.0 \pm 5.6^{*, \# \#}$
\end{tabular}

${ }^{*} P<0.05,{ }^{* *} P<0.01$, compared with the control; ${ }^{\#} P<0.05,{ }^{\#} P<0.01$, compared with HR-1.

Table 3. Scratching behavior induced by substance $P$ in HR-1, $\mathrm{NC} / \mathrm{Nga}$, ICR, and ddY mice

\begin{tabular}{lcc}
\hline Strains & Dose (nmol/site, i.d.) & Scratches per $60 \mathrm{~min}$ \\
\hline HR-1 & - & $11.4 \pm 2.7$ \\
& 10 & $17.9 \pm 3.4$ \\
& 100 & $30.3 \pm 5.5^{* *}$ \\
NC/Nga & - & $15.3 \pm 3.2$ \\
& 10 & $26.8 \pm 3.3$ \\
ICR & 100 & $54.0 \pm 4.1^{* *, \#}$ \\
& - & $28.2 \pm 7.1$ \\
& 10 & $40.9 \pm 7.9^{\#}$ \\
ddY & 100 & $56.9 \pm 6.4^{*, \#}$ \\
& - & $11.4 \pm 1.9$ \\
& 10 & $26.4 \pm 3.1$ \\
& 100 & $62.3 \pm 8.5^{* *, \# \#}$ \\
\hline
\end{tabular}

${ }^{*} P<0.05,{ }^{* *} P<0.01$, compared with the control; ${ }^{\#} P<0.05,{ }^{\#} P<0.01$, compared with HR-1.

HR-1 mice induced by $100 \mathrm{nmol} / \mathrm{site}$ serotonin was more than those in $\mathrm{NC} / \mathrm{Nga}(100 \mathrm{nmol} / \mathrm{site})$ and $\mathrm{ddY}$ mice (10 and $100 \mathrm{nmol} / \mathrm{site})$ (Table 2).

\section{Substance P-induced scratching behavior}

Substance P caused a dose-dependent increase in the number of scratching behaviors in all four mice, and a significant effect was observed at a dose of 100 $\mathrm{nmol} / \mathrm{site}$. The number of scratching behaviors in HR-1 mice induced by substance $P$ was significantly less than those of ICR mice at 10 and $100 \mathrm{nmol} /$ site and those of $\mathrm{NC} / \mathrm{Nga}$ and ddY mice at $100 \mathrm{nmol} /$ site (Table 3).

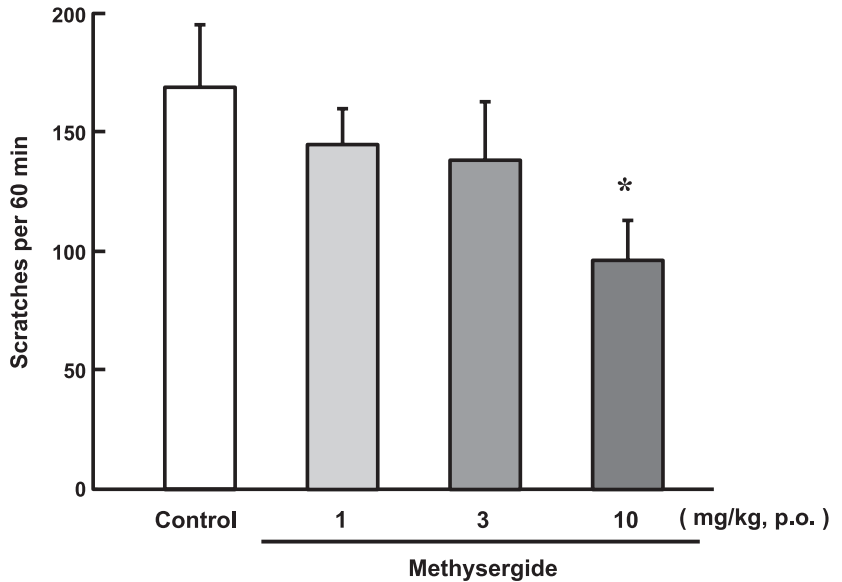

Fig. 2. Effect of methysergide on compound 48/80-induced scratching behavior in HR-1 mice. Scratching behavior was counted for $60 \mathrm{~min}$ after intradermal injection of $10 \mu \mathrm{g} /$ site compound 48/80. Methysergide at doses of 1,3 , or $10 \mathrm{mg} / \mathrm{kg}$ was orally administered $1 \mathrm{~h}$ before injection of compound 48/80. Each value represents the mean \pm S.E.M. $(\mathrm{n}=8) . *$ : Significantly different from the control group at $P<0.05$.

Effect of methysergide on compound 48/80-induced scratching behavior

Methysergide at doses of 1 and $3 \mathrm{mg} / \mathrm{kg}$ caused no antagonizing effect on compound 48/80-induced scratching behavior; however, at a dose of $10 \mathrm{mg} / \mathrm{kg}$, it caused a significantly antagonistic effect (Fig. 2).

\section{Discussion}

In the present study, it was found that compound $48 / 80$ induced scratching behavior in all strains of mice used. Among them, HR-1 and ICR mice showed a high response to compound $48 / 80$. On the other hand, $\mathrm{NC} / \mathrm{Nga}$ and ddY mice are low responders to compound $48 / 80$. Kuraishi et al. (8) reported that when compound $48 / 80$ at a dose of $10 \mu \mathrm{g}$ was injected intradermally into ddY mice, the number of scratching behaviors per $60 \mathrm{~min}$ was about 30 times. In our present study, scratching behavior in ddY mice was at most 50 times. Therefore, it is reasonable to conclude that ddY mice are less sensitive to compound $48 / 80$ than the other strains. On the other hand, in ICR mice, it has been reported that the number of scratching behaviors induced by $10 \mu \mathrm{g}$ compound $48 / 80$ is about 200 times per $60 \mathrm{~min}(9)$ and they concluded that ICR mice showed the highest response to serotonin among the examined strains. Almost the same findings were also observed in ICR in the present study. The number of scratching behaviors in HR- 1 mice induced by compound $48 / 80$ is almost the same as ICR mice at doses of 1,3 , and $10 \mu \mathrm{g} / \mathrm{site}$. Therefore, it seems likely that HR-1 mice are good 
responders for scratching behavior against compound $48 / 80$, similar to ICR mice.

It is well known that compound $48 / 80$ is a potent activator of connective tissue-type and/or skin mast cells (10). Therefore, it is reasonable to presume that the scratching behavior caused by compound $48 / 80$ may be effected via mediators released from mast cells, such as histamine, serotonin, and substance P $(11-14)$. To investigate which chemical mediators are most responsible for compound 48/80-induced scratching behavior in HR-1 mice, some chemical mediators were injected and the number of scratching behaviors was measured.

As a result, similar to NC/Nga and ddY mice, HR-1 mice showed far less sensitivity to histamine than the ICR mice. Almost the same findings had been demonstrated by Inagaki et al. (9) and Kuraishi et al. (8) that histamine induced a significant increase in scratching behavior only in ICR mice, and no significant increase was observed in $\mathrm{NC} / \mathrm{Nga}$ or ddY mice. From these findings, Inagaki et al. (9) concluded that ICR mice are good responders for scratching behavior against various stimulus, especially against histamine. On the other hand, as shown in the text, similar to ICR mice, HR-1 mice are more sensitive to serotonin than $\mathrm{NC} / \mathrm{Nga}$ and ddY mice, and at a dose of $100 \mathrm{nmol} /$ site serotonin; HR-1 mice are more sensitive to ICR mice. In addition, compound 48/80-induced scratching behavior in HR-1 mice was significantly inhibited by methysergide at a dose of $10 \mathrm{mg} / \mathrm{kg}$. From these findings, we supposed that the scratching behavior induced by compound 48/80 in HR-1 mice is mainly attributable to serotonin. However, Inagaki et al. (7) reported that serotonin plays only a minor role in the incidence of scratching behavior by compound $48 / 80$ in BALB/c mice from the findings that a relatively large dose $(300 \mathrm{nmol})$ is needed to induce significant scratching behavior, and the scratching behavior induced by $300 \mathrm{nmol}$ serotonin is less frequent than that induced by $100 \mu \mathrm{g}$ of compound $48 / 80$. This finding in BALB/c mice was different from the present results of HR-1 mice. At present, we have no good explanation as to why there is a great difference between HR-1 and BALB/c mice in sensitivity to serotonin.

As shown in the text, HR-1 mice showed less sensitivity to substance $\mathrm{P}$ than NC/Nga, ICR, and ddY mice. Inagaki et al. (9) reported that scratching behavior due to substance $\mathrm{P}$ was increased in $\mathrm{NC} / \mathrm{Nga}, \mathrm{ICR}$, and ddY mice, the increase in $\mathrm{Nc} / \mathrm{Nga}$ mice was negligible, and that in ddY was moderate. The finding by Inagaki et al. is almost the same as our present data, suggesting that HR-1 is low responder to substance P.

In summary, the scratching behavior induced by compound 48/80 in HR-1 mice is mainly attributable to serotonin, and this mouse can be used as dermatitis model accompanied by pruritus, caused mainly by serotonin.

\section{References}

1 Matsuda H, Watanabe N, Geba GP, Sperl J, Tsudzuki M, Hiroi J, et al. Development of atopic dermatitis-like skin lesion with IgE-hyperproduction in NC/Nga mice. Int Immunol. 1997;9: 461-466.

2 Suto $\mathrm{H}$, Matsuda $\mathrm{H}$, Mitsuishi $\mathrm{K}$, Hira $\mathrm{K}$, Uchida $\mathrm{T}$, Unno $\mathrm{T}$, et al. NC/Nga mice: a mouse model for atopic dermatitis. Int Arch Allergy Immunol. 1999;120:70-75.

3 Vestergaard C, Yoneyama H, Matsushima K. The NC/Nga mouse: a model for atopic dermatitis. Mol Med Today. 2000;6:209-210.

4 Aioi A, Tonogaito H, Suto H, Hamada K, Ra C, Ogawa LRA, et al. Impairment of skin barrier function in NC/Nga Tnd mice as a possible model for atopic dermatitis. $\mathrm{Br} \mathrm{J}$ Pharmacol. 2001;144:12-18.

5 Matsumoto K, Mizukoshi K, Oyobikawa M, Ohshima H, Tagami H. Establishment of an atopic dermatitis-like skin model in a hairless mouse by repeated elicitation of contact hypersensitivity that enables to conduct functional analyses of the stratum corneum with various non-invasive biophysical instruments. Skin Res Technol. 2004;10:122-129.

6 Kligman LH, Murphy GF. Topical tretinoin increases dermal mast cells, induces epidermal mast cell growth factor (c-kit ligand) and modulates its distribution in hairless mice. Arch Dermatol Res. 1996;228:537-542.

7 Inagaki N, Igeta K, Kim JF, Nagao M, Shiraishi N, Nakamura N, et al. Involvement of unique mechanisms in the induction of scratching behavior in BALB/c mice by compound $48 / 80$. Eur $\mathrm{J}$ Pharmacol. 2002;448:175-183.

8 Kuraishi Y, Nagasawa T, Hayashi K, Satoh M. Scratching behavior induced by pruritogenic but not algesiogenic agents in mice. Eur J Pharmacol. 1995;275:229-233.

9 Inagaki N, Nagao M, Igeta K, Kawasaki H, Kim JF, Nagai H. Scratching behavior in various strains of mice. Skin Pharmacol Appl Skin Physiol. 2001;14:87-96.

10 Benyon RC, Robinson C, Church MK. Differential release of histamine and eicosanoids from human skin mast cells activated by IgE-dependent and non-immunological stimuli. $\mathrm{Br} \mathrm{J}$ Pharmacol. 1989;97:898-904.

11 Yamaguchi T, Nagasawa T, Satoh M, Kuraishi Y. Itch-associated response induced by intradermal serotonin through 5-HT2 receptors in mice. Neurosci Res. 1999;35:77-82.

12 Rukwied R, Lischetzki G, McGlone F, Heyer G, Schmilz M. Mast cell mediators other than histamine induce pruritus in atopic dermatitis patterns: a dermal microdialysis study. Br J Pharmacol. 2000;142:1114-1120.

13 Sugimoto Y, Nakamura Y, Hossen MA, Watanabe T, Kamei C. Evaluation of the effects of anti-pruritic drugs on scratch responses using $\mathrm{H} 1$ receptor deficient mice. Eur J Pharmacol. 2003;470:113-116.

14 Ohmura T, Hayashi T, Satoh Y, Konomi A, Jung B, Sato H. Involvement of substance $\mathrm{P}$ in scratching behavior in an atopic dermatitis model. Eur J Pharmacol. 2004;491:191-194. 